\title{
Environmentally relevant cadmium concentrations affect development and induce apoptosis of Paracentrotus lividus larvae cultured in vitro
}

\author{
Simone Filosto • Maria Carmela Roccheri • \\ Rosa Bonaventura $\cdot$ Valeria Matranga
}

Received: 13 December 2007 / Accepted: 4 February 2008

(C) Springer Science + Business Media B.V. 2008

\begin{abstract}
Sea urchin embryos and larvae represent suitable model systems on where to investigate the effects of heavy metals on development and cell viability. Here, we tested the toxic effects of low $\left(10^{-12} \mathrm{M}\right)$, medium $\left(10^{-9} \mathrm{M}\right)$, and high $\left(10^{-6} \mathrm{M}\right)$ cadmium chloride concentrations, mimicking unpolluted, moderately and highly polluted seawaters, respectively, on Paracentrotus lividus sea urchins offspring. Larvae were continuously treated from fertilization and inspected at time intervals comprised between 10 and 30 days of development. Delays and/ or morphological abnormalities were firstly evident in larvae treated for 15 days with high cadmium $\left(10^{-6} \mathrm{M}\right)$ and for 25 days with medium cadmium $\left(10^{-9} \mathrm{M}\right)$. Major defects consisted in the reduction and lack of arms and skeleton elongation. No obvious differences with respect to controls were observed in embryos/larvae exposed to low cadmium $\left(10^{-12} \mathrm{M}\right)$, even after 30 days of exposure. Using in situ terminal deoxynucleotidyl transferase-mediated dUTP nick-
\end{abstract}

S. Filosto $\cdot$ M. C. Roccheri $(\bowtie)$

Dipartimento di Biologia Cellulare e dello Sviluppo

"A. Monroy", University of Palermo,

Viale delle Scienze,

90128 Palermo, Italy

e-mail: mariroc@unipa.it

R. Bonaventura $\cdot$ V. Matranga

Istituto di Biomedicina e Immunologia Molecolare

“A. Monroy", Consiglio Nazionale delle Ricerche,

Palermo, Italy end labeling assay (TUNEL) assay on larvae whole mounts, we detected apoptosis after 10 days of treatment with $10^{-6}$ and $10^{-9} \mathrm{M} \mathrm{CdCl}_{2}$, when no morphological abnormalities were recognizable yet. Supernumerary apoptotic cells were found in arm buds, ciliary bands, and apex. In conclusion, echinoderm embryos and larvae represent candidates of choice for the study of stress and defense mechanisms activated by cadmium exposure.

Keywords Cadmium - Development . DNA fragmentation · Sea urchin · Skeleton · TUNEL assay

\section{Introduction}

Among heavy metals, a few, like copper, selenium, and zinc, are essential in trace amounts for the maintenance of living organisms metabolism; others, like cadmium, do not have any biological role and are toxic even at very low concentrations (Foulkes 2000). Toxic heavy metals enter into cells through the nutrient transport systems and affect cell activities by substituting the latter in their metabolic sites (Sunda and Huntsman 1998). As a result, by a process which is referred to as molecular and ionic mimicry, mercury, cadmium, lead, arsenic, selenium, and others are transported to target organs and tissues (Bridges and Zalups 2005). Toxic effects of cadmium 
have been well documented in a wide range of different species: teratogenesis in Xenopus laevis (Mouchet et al. 2006, 2007) and carcinogenesis in Syrian hamsters are useful examples of its toxicity (Waalkes and Rehm 1998). In addition, cadmium is irreversibly accumulated into cells, as it has been demonstrated in rat organs and marine mollusks (Roesijadi et al. 1996; Haouem et al. 2007). The mechanisms by which cadmium interacts with cellular components and molecular targets are probably various, though still poorly understood. Experimental evidences suggest that the metal crosses the plasma membrane as bivalent ion, $\mathrm{Cd}^{2+}$, exerting an agonistic role against calcium ionic channels (Viarengo and Nicotera 1991; Rainbow et al. 2005). Cadmium has been associated to: blockage of oxidative phosphorylation, glutathione depletion and antioxidant enzymatic activity inhibition, production of ROS, DNA damage, and inhibition of relative repair mechanisms, a general reduction of protein synthesis coupled to an increase in stress proteins (hsps), (Kesseler et al. 1994; Shimizu et al. 1997; Ercal et al. 2001; Schröder et al. 1999, 2005; Lin et al. 2007; Roccheri et al. 2004). Cellular effects, modifications of biomolecules, modulation of DNA repair and genotoxic consequences induced by cadmium in human cells have been extensively reviewed elsewhere (Bertin and Averbeck 2006). Furthermore, the occurrence of apoptotic events after cadmium exposure has been demonstrated in several cell types (Habeebu et al. 1998; Tsangaris and Tzortzatou-Stathopoulou 1998; Ishido et al. 1999; Risso-de Faverney et al. 2001; Kim et al. 2002; Agnello et al. 2007).

The presence in the environment of this metal has grown because of its large employment in some industrial and agricultural activities (Rule et al. 2006). Although heavy metals are terrestrially produced, they flow into the sea through effluent and sewage or are directly discharged from industries placed on the seawater front. In addition to its release into costal waters, cadmium fallout, following atmospheric events, contributes to marine ecosystems pollution (Chalmers et al. 2007). Echinoderm embryos and larvae represent widely used experimental models for testing the effects of stressors, like heavy metals, on development and cell viability because they are highly sensitive to chemical and physical environmental changes (Lesser et al. 2003; Kobayashi and Okamura 2004; Vega and Epel 2004; Pellerito et al.
2005). In addition, they occupy a peculiar position and role in the marine trophic chain as part of the diet of several planktonic and benthonic organisms (Hays et al. 2005).

In previous studies, we demonstrated that exposure to $\mathrm{CdCl}_{2}$ induced morphological abnormalities and apoptosis in Paracentrotus lividus embryos with timeand concentration-dependent modes, also showing that cadmium was accumulated to a certain extent into sea urchin embryos (Roccheri et al. 2004; Agnello et al. 2006, 2007). In this work, we extended our studies to metamorphosis-competent larvae with the purpose of measuring the effects of long-lasting continuous exposure to cadmium concentrations similar to those occurring in polluted environments. Developmental abnormalities were scored at different time intervals and compared with control larvae, and DNA fragmentation was assessed by in situ terminal deoxynucleotidyl transferase-mediated dUTP nickend labeling assay (TUNEL) assays on whole mounts. Cadmium concentrations we used in this work (from $112 \times 10^{-6} \mu \mathrm{g} / \mathrm{L}$ to $112 \mu \mathrm{g} / \mathrm{L}$ ) were chosen on the basis of two criteria: (1) much lower than those used in previous work (Roccheri et al. 2004) to expose embryos for longer periods of time and (2) similar to those found in natural or polluted seawaters, to make possible a comparison between laboratory experiments and field studies. It should be considered that cadmium concentrations determined in the field vary very much according to different seawater latitudes and depths. Specifically, cadmium concentration in the Northern Atlantic Ocean is about $4 \times 10^{-3} \mu \mathrm{g} / \mathrm{L}$ $\left(4 \times 10^{-6} \mathrm{ppm}\right.$; Kremling and Streu 2001), whereas in the Baltic Sea, it is comprised of between 12 and $16 \times$ $10^{-3} \mu \mathrm{g} / \mathrm{L}$ (12 and $16 \times 10^{-6} \mathrm{ppm}$; Pohl and Hennings 2005). Surface water samples collected from noncontaminated and polluted sites in the Kyoto area showed that cadmium content in natural seawaters was about $27 \times 10^{-3} \mu \mathrm{g} / \mathrm{L}\left(27 \times 10^{-6} \mathrm{ppm}\right)$, whereas in seawaters around Kanayama (disused lead mine), the metal concentration raised to $12 \mu \mathrm{g} / \mathrm{L}\left(12 \times 10^{-3} \mathrm{ppm}\right)$, a thousandfold more (Kobayashi and Okamura 2004, 2005). Similarly, along the Galitian coasts (NW of the Iberian Peninsula), metal concentration in the seawater ranged from $13.4 \times 10^{-3}$ to $1.49 \mu \mathrm{g} / \mathrm{L}\left(13.4 \times 10^{-6}-\right.$ $1.49 \times 10^{-3} \mathrm{ppm}$ ), depending on pollution of different sites (Beiras et al. 2003). In addition, it should be considered that metal concentrations in seawater can be strongly influenced by fresh water discharges from 
heavily polluted rivers. For example, the Rhon river and other rivers that open into the Gulf of Lion determine high cadmium levels comprised of between $0.6 \times 10^{-3}$ and $1.1 \times 10^{-3} \mu \mathrm{g} / \mathrm{L}(0.6$ and $1.1 \mathrm{ppm}$; Radakovitch et al. 2008). Similarly, it was reported that in the Northern Adriatic Sea, quite elevated cadmium concentrations up to $9.32 \times 10^{-3} \mu \mathrm{g} / \mathrm{L}$ $\left(9.32 \times 10^{-6} \mathrm{ppm}\right)$ were measured at the Po river efflux (Tankere and Statham 1996). For what the natural habitat of $P$. lividus specimens used for this study is concerned, a recent report accounts for cadmium levels comprised of between $0.56 \times 10^{-3}$ and $80.4 \times 10^{-3} \mu \mathrm{g} / \mathrm{L}$ $\left(0.56 \times 10^{-6}-80.4 \times 10^{-6} \mathrm{ppm}\right)$ in the Mediterranean sea around the Sicily island (Censi et al. 2002).

\section{Material and methods}

Embryo and larvae culture

Adults of P. lividus were collected in the northwestern coast of Sicily and used to obtain gametes through the injection of $0.5 \mathrm{M}$ Potassium Chloride into the coelomic cavity. Eggs were washed several times with filtered natural seawater (SW). Dry sperm was kept at $4^{\circ} \mathrm{C}$ until use. Eggs were fertilized, washed several times in SW, and cultured in Millipore-filtered SW (0.22-mm pore membranes; MFSW) at $18^{\circ} \mathrm{C}$. At 2 days after fertilization, pluteus larvae were cultured in MFSW in sterile containers at $18^{\circ} \mathrm{C}$, while being gently stirred at $30 \mathrm{rpm}$ with a rotator, and fed as previously described (Yokota et al. 2002). Half of the MFSW was changed once a week. Larvae were staged by optical inspection every 3 days. Larvae reached the six-armed stage after 10-12 days, the eight-armed stage after 15-20 days, and after 28-30 days, larvae were competent to metamorphose.

\section{Exposures to cadmium}

Treatment was performed continuously, just after fertilization, by adding cadmium chloride to MFSW at the following different concentrations: $10^{-6} \mathrm{M}$ $(112 \mu \mathrm{g} / \mathrm{L}$ equivalent to $0.112 \mathrm{ppm}), 10^{-9} \mathrm{M}(112 \times$ $\left.10^{-3} \mu \mathrm{g} / \mathrm{L}\right)$, and $10^{-12} \mathrm{M}\left(112 \times 10^{-6} \mu \mathrm{g} / \mathrm{L}\right)$. For the sake of clarity in the following text, we will refer to the aforementioned concentrations to as high, medium, and low cadmium, respectively.
Cadmium chloride was added from three 1,000fold stock solutions $\left(10^{-3}, 10^{-6}\right.$, and $\left.10^{-9} \mathrm{M}\right)$ and reconstituted every week at the time of MFSW change. Larvae development was monitored by optical microscopy and compared to larvae cultures in MFSW at days 10, 15, 20, 25, and 30. Images were recorded by a Zeiss Axioscop 2 plus microscope, equipped with a digital camera.

\section{TUNEL assay}

TUNEL assay (Promega) was performed on whole mount larvae. Larvae were fixed with a solution of $3.7 \%$ paraformaldehyde in MFSW, washed several times in MFSW, and permeabilized with $-20^{\circ} \mathrm{C}$ methanol, washed with MFSW and phosphate-buffered saline Tween $20\left(0.15 \mathrm{M} \mathrm{Na}_{2} \mathrm{HPO} 4,0.04 \mathrm{M} \mathrm{NaH}_{2} \mathrm{PO}_{4}\right.$, $0.15 \mathrm{M} \mathrm{NaCl}, 0.05 \%$ Tween-20) and then incubated for $60 \mathrm{~min}$ at $37^{\circ} \mathrm{C}$ with $50 \mu \mathrm{l}$ of a solution containing the following reagents: equilibration buffer, TdT enzyme $(10 \mathrm{U})$, and fluorescent nucleotide mix $(5 \mu \mathrm{M}$ fluorescein 12-dUTP). Negative controls were incubated in the same mixture but without the TdT enzyme; positive controls were pretreated with DNAse $(10 \mu \mathrm{g} / \mathrm{ml})$ before the TdT assay. Nuclei were stained by incubating with propidium iodide $(2 \mu \mathrm{g} / \mathrm{ml})$. The reaction was stopped by incubating the larvae with $\mathrm{NaCl} /$ sodium citrate $(300 \mathrm{mM} / 30 \mathrm{mM})$ for $15 \mathrm{~min}$. Stained larvae were observed using confocal laser scanning microscopy (Olympus FV 300 with a He-Ne 543 nm laser).

\section{Results}

To evaluate if cadmium concentrations next to those found in moderately and highly polluted seawaters could trigger cytotoxic effects, $P$. lividus embryos batches were continuously cultured just after fertilization in the presence of different metal concentrations, namely, culturing seawater was supplemented with $10^{-12} \mathrm{M}$ (low), $10^{-9} \mathrm{M}$ (medium), and $10^{-6} \mathrm{M}$ (high) $\mathrm{CdCl}_{2}$ final concentrations, corresponding to metal values found in unpolluted, moderately polluted, and extremely polluted seawaters, respectively. To score for the presence of morphological abnormalities, microscopic inspection was performed at days $10,15,20,25$, and 30 of cadmium exposure. Results were expressed as the percentage of scored organisms in 100\% sample (about 
100 larvae for each experimental point), based on three major morphological categories found: normal, developmentally delayed and abnormal larvae, i.e., with defects in arm and skeleton elongation and a reduction of rudiment growth (Fig. 1). After 10 days of treatment, larvae had morphological characteristics similar to controls for all concentrations tested. Some defects became clearly evident after 15 days of treatment only for larvae exposed to high cadmium, showing $35 \%$ of developmental delays and $45 \%$ of abnormalities (Fig. 1c). A 20-day treatment was necessary to induce $80 \%$ developmental delays and $2.5 \%$ abnormalities in
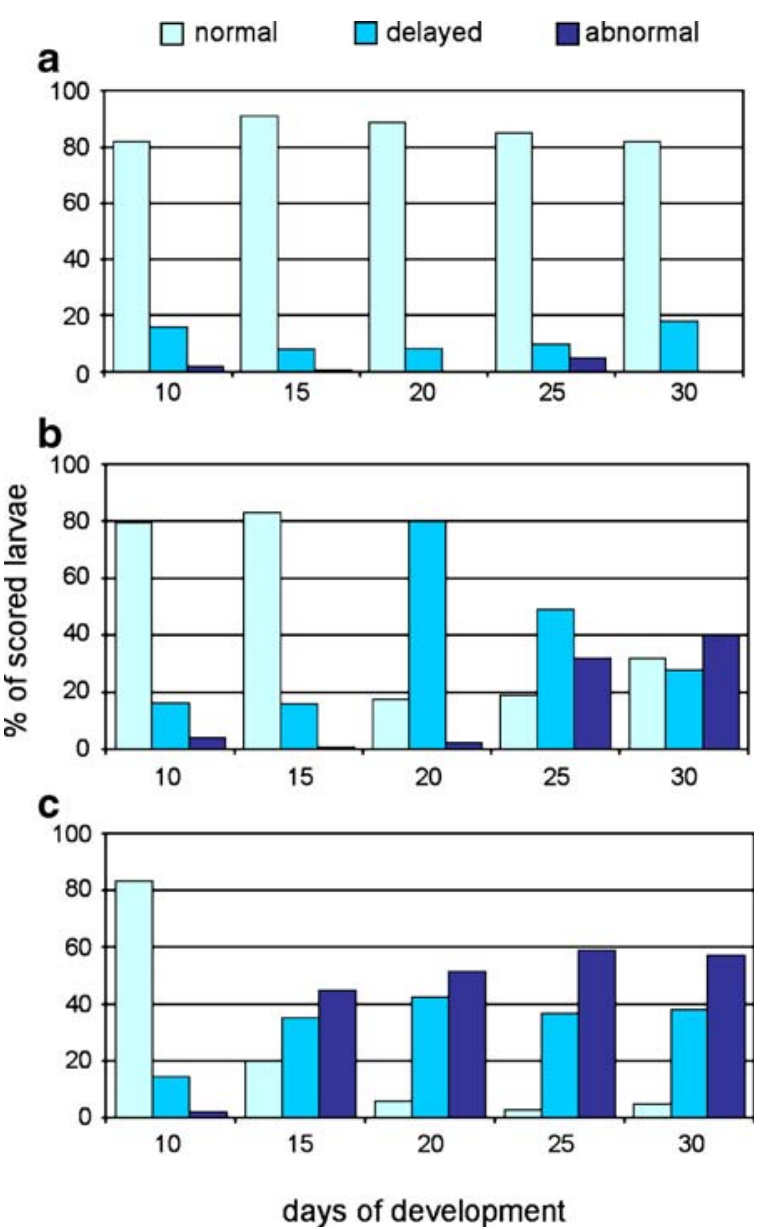

Fig. 1 Perturbation of larvae development correlates with the increase in cadmium concentration. Histograms show the amount of normal (light blue bars), delayed (turquoise bars), and abnormal (dark blue bars) larvae microscopically inspected at $10,15,20,25$, and 30 days post-fertilization, expressed as percentage of organisms scored (100-150 larvae per each experimental point). Larvae were exposed to: a low cadmium $\left(10^{-12} \mathrm{M}\right)$, b medium cadmium $\left(10^{-9} \mathrm{M}\right)$, and $\mathbf{c}$ high cadmium $\left(10^{-6} \mathrm{M}\right)$. Data from a representative experiment larvae exposed to medium cadmium (Fig. 1b), whereas $42 \%$ delays and $52 \%$ abnormalities were observed in larvae exposed to high cadmium for the same time length (Fig. 1c). Further delays and abnormalities were more evident throughout development for both medium and high cadmium. Larvae treated with the lowest cadmium concentration continued normal development until metamorphosis (30 days), suggesting that this condition was not sufficient to cause irreparable damages (Fig. 1a). The physiological development of $P$. lividus from the eight-armed pluteus larva to metamorphosis is illustrated in Fig. 2a-d). Briefly, when the four-armed pluteus larvae are properly fed (with algae and/or diatoms, see Yokota et al. 2002), they develop through a six-armed stage into eight-armed larvae, as observed after 15 days (Fig. 2a). An echinus rudiment is gradually formed from the left coelomic pouch which differentiates at the side of the archenteron (primitive intestine) after 20 days (Fig. 2b). The rudiment continues to grow (Fig. 2c) and eventually everts from the feeding larva after about 30 days (Fig. 2d). It should be recalled here that studies on feeding mechanisms indicate that echinoderm larva arms and ciliary bands are effective in the capture of suspended food particles that are subsequently transported downward towards the mouth. In addition, their capturing ability is proportional to the length of the ciliary bands (Hart 1996). Upon cadmium exposure, aberrant morphologies were observed with different proportions (see Fig. 1); defects were found essentially in arms and rudiment, which appeared malformed or absent. When comparing development of 15-day larvae treated with high cadmium with normal larvae, we found an evident delay: larvae appeared much smaller in size and showed only the beginning of the third pair of arms (see arrows, Fig. 2e). As already mentioned, timeand dose-dependent major abnormalities were found, consisting in elongation and patterning defects of arms and skeleton; particularly, larvae have some arms shorter than the others (see arrows, Fig. $2 \mathrm{f}-\mathrm{h}$ ). In addition, the rudiment did not grow, probably as a result of a deficient recruitment of food (see Fig. $2 \mathrm{f}-\mathrm{h}$ ). As medium and high cadmium caused morphological and developmental aberrations before metamorphosis, we investigated on putative effects produced at the molecular level. Thus, to evaluate apoptosis induced by cadmium, we performed DNA fragmentation assays by terminal uridine deoxynucleotidyl transferase dUTP nick-end labeling (TUNEL) on larvae whole mounts 


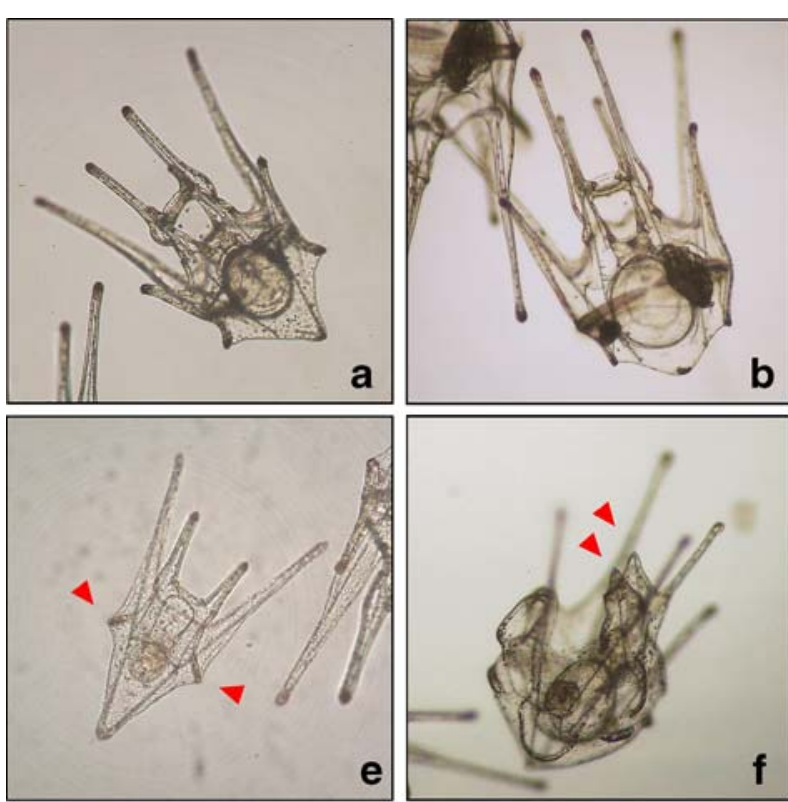

Fig. 2 Developmental defects in larvae exposed to different cadmium concentrations. Physiological development of Paracentrotus lividus larvae until metamorphosis: a eight-armed pluteus larva (15 days), b eight-armed pluteus with small rudiment (20 days), c eight-armed pluteus with large rudiment

before apparent defects were detectable, if any, at all concentrations tested (10 days after treatment). As shown in Fig. 3, apoptosis was evident in a large number of cells in larvae treated with both medium (Fig. 3g-i) and high (Fig. 3j-1) cadmium. Merge images evidenced that interested territories were: arms, ciliary bands, and apex. It should be noted that the extent of apoptosis was similar both in well-timed developed or delayed larvae (compare Fig. 31 with i). A certain amount of apoptosis was also found in low cadmium in the same cellular territories (Fig. 3d-f), whereas a smaller number of apoptotic cells were found only in arms of control larvae (Fig. 3a-c). This finding is not surprising, as we have already shown that a physiological apoptosis occurs in pre-metamorphic larvae (Roccheri et al. 2002).

\section{Discussion}

Some trace metals, including cadmium, are potentially toxic to marine organisms. The toxic effects of heavy metals have been studied in echinoderm embryos, which are subjected to the risk of contamination in their habitat. In this paper, we demonstrated that long-
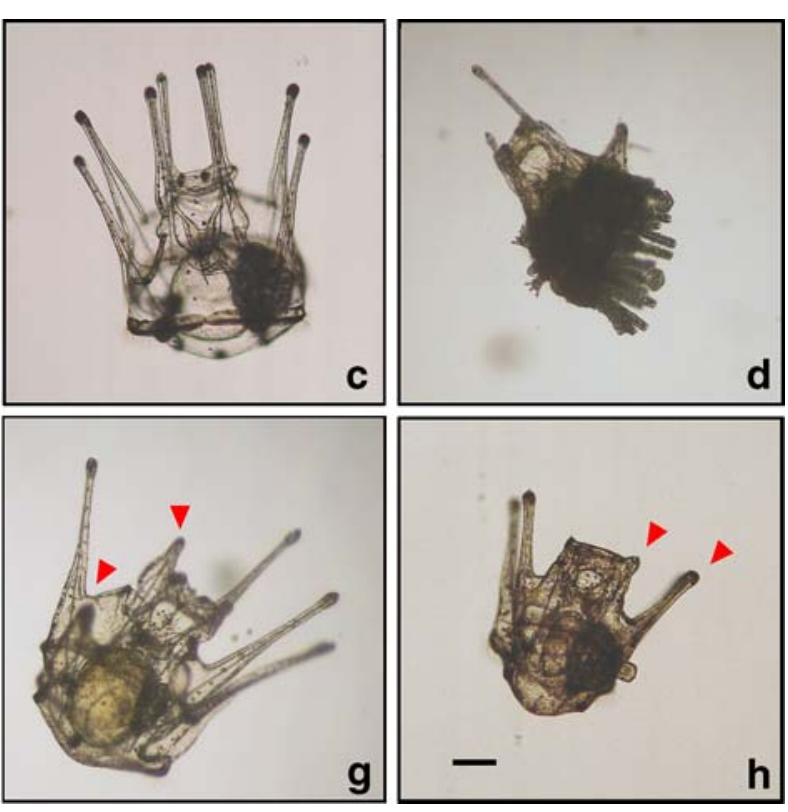

(25 days), and $\mathbf{d}$ metamorphosis competent larva everting juvenile (30 days). Impairment of development in larvae exposed to cadmium: e $10^{-6} \mathrm{M}, 15$ days; f $10^{-9} \mathrm{M}, 20$ days; g $10^{-6}$ M, 25 days; h $10^{-9}$ M 30 days. Bar $=100 \mu \mathrm{m}$

lasting exposure to cadmium concentrations similar to those found in moderately or highly polluted seawaters caused severe developmental delays and abnormalities during time in culture. As an example, abnormalities similar to those observed after a 25-day treatment with medium cadmium $\left(112 \times 10^{-3} \mu \mathrm{g} / \mathrm{L}\right)$ were found in larvae exposed for shorter time lengths (15 days) with high cadmium $(112 \mu \mathrm{g} / \mathrm{L})$. In conclusion, the reported data suggest that even very small amounts of cadmium, if accumulated into cells, produce significant cytotoxic effects. Similarly, it has been reported that heavy metals, including cadmium, have a dose-dependent inhibitory effects in sea urchin embryos and larvae development. (Kobayashi and Okamura 2004, 2005). Therefore, the occurrence of abnormalities would depend on cell loss caused by extensive apoptosis. Here, we demonstrated that 10 days of treatment were sufficient to cause DNA fragmentation related to apoptotic events in larvae exposed to medium or high cadmium. A supernumerary number of cells undergoing apoptosis could then interfere with the developing program, causing a miss-regulation of cellular remodeling, which normally occurs in pre-metamorphic stages of development. The resulting defects in arms and ciliary bands probably disturb the correct larval 
Fig. 3 Evaluation of DNA fragmentation by TUNEL assay. Whole mounts of larvae were observed after 10 days of development. Three-dimensional reconstruction of the images of larvae observed under confocal laser microscopy. In green, DNA fragmentation $(\mathbf{a}, \mathbf{d}, \mathbf{g}, \mathbf{j})$; in red, nucleic acids (propidium iodide; $\mathbf{b}$, $\mathbf{e}, \mathbf{h}, \mathbf{k})$; merges of green and red (c, f, i, l). Larvae treated with low $(\mathbf{d}-\mathbf{f})$, me$\operatorname{dium}(\mathbf{g}-\mathbf{i})$, and high $(\mathbf{j}-\mathbf{l})$ cadmium; control larvae (a-c); Bar $=100 \mu \mathrm{m}$

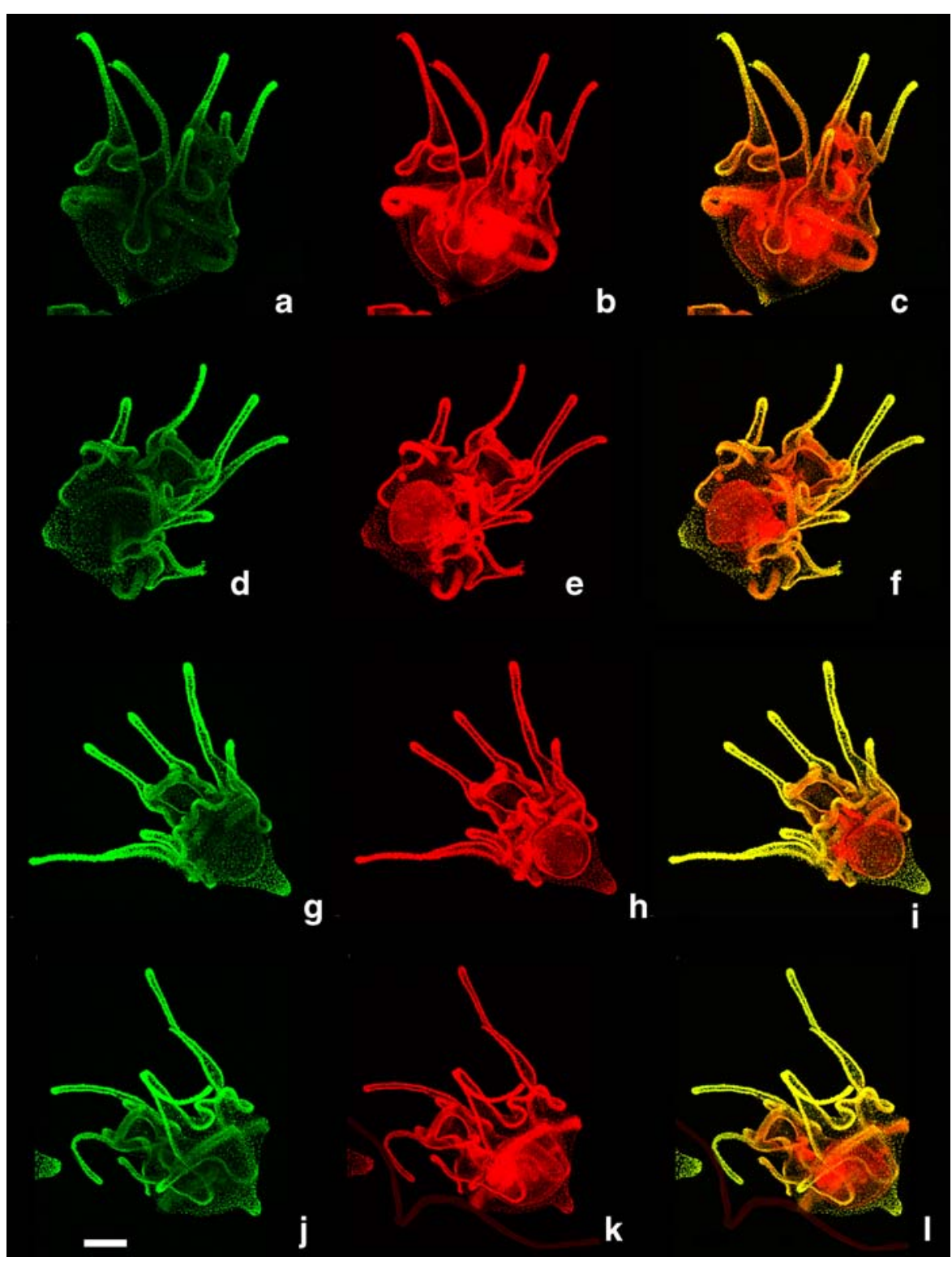

feeding behavior which has been shown to be necessary for adult rudiment growth (Yazaki 2002). It is known that sea urchin embryos and larvae can activate physiological mechanisms of programmed cell death at specific developmental stages (Roccheri et al. 2002; Sato et al. 2006; Vega Thurber and Epel 2007), but an increase of apoptotic processes was observed in response to the accumulation of cadmium in embryos (Agnello et al. 2006, 2007) and larvae (present work). Apoptosis is supposed to be a way of removing cells whose DNA has been heavily damaged by cadmium, as documented in the case of a vertebrate model system (Hamada et al. 1997). Thus, we can assume that also in sea urchin embryos/larvae, apoptosis can be considered as part of a defense strategy in response to cadmium.

All together, our findings are in agreement with other studies performed in different organisms. For example, cadmium induces ectopic apoptosis in zebrafish embryos where the number of apoptotic cells has been related to degrees of major developmental malformations (Chan and Cheng 2003). Similarly, an increase in the incidence of apoptosis, tested by whole-mount in situ TUNEL method, was observed in crustacean larvae with a 
concomitant increase in cadmium concentration (Cheng et al. 2004). In conclusion, despite their high resistance to chemicals during their embryonic life described by other authors (Hamdoun and Epel 2007), sea urchin larvae continuously exposed to cadmium from fertilization, accumulate abnormalities during time. Although recent studies have investigated on the mechanisms by which different chemicals affect sea urchin embryonic development, detailed defense mechanisms are not yet described (Goldstone et al. 2006). The molecular pathways activated in response to cadmium have been partially described in our previous work and involved hsps synthesis (Roccheri et al. 2004), DNA damage as single cell breaks (Schröder et al. 2005), metallothionein gene expression (Russo et al. 2003), and caspase-3 activation (Agnello et al. 2007). Experiments in progress seem to imply the activation of free oxygen radicals (ROS) and p38 MAPk, whose activation has been demonstrated in response to UV-B (Bonaventura et al. 2005) and other physical stresses (Casano et al. 2003). As the sea urchin is a well-established model system where to study development, it is a candidate of choice for addressing stress and defense mechanisms activated by cadmium.

Acknowledgements This work was supported by grants from MIUR (ex 60\%) and partially by the ASI MoMa project (contract 1/014/06/0).

\section{References}

Agnello M, Filosto S, Scudiero R, Rinaldi AM, Roccheri MC. Cadmium accumulation induces apoptosis in $P$. lividus embryos. Caryologia 2006;59:403-8.

Agnello M, Filosto S, Scudiero R, Rinaldi AM, Roccheri MC. Cadmium induces apoptotic response in sea urchin embryos. Cell Stress Chaperones 2007;12:44-50.

Beiras R, Bellas J, Fernández N, Lorenzo JI, Cobelo-García A. Assessment of coastal marine pollution in Galicia (NW Iberian Peninsula); metal concentrations in seawater, sediments and mussels (Mytilus galloprovincialis) versus embryo-larval bioassays using Paracentrotus lividus and Ciona intestinalis. Mar Environ Res 2003;56:531-53.

Bertin G, Averbeck D. Cadmium: cellular effects, modifications of biomolecules, modulation of DNA repair and genotoxic consequences. Biochimie 2006;88(11):1549-59.

Bonaventura R, Poma V, Costa C, Matranga V. UVB radiation prevents skeleton growth and stimulates the expression of stress markers in sea urchin embryos. Biochem Biophys Res Commun 2005;328(1):150-7.
Bridges CC, Zalups RK. Molecular and ionic mimicry and the transport of toxic metals. Toxicol Appl Pharmacol 2005;204(3):274-308.

Casano C, Roccheri MC, Maenza L, Migliore S, Gianguzza F. Sea urchin deciliation induces thermoresistance and activates the p38 mitogen-activated protein kinase pathway. Cell Stress Chaperones 2003;8(1):70-5.

Censi P, Mazzola S, Alonzo G, Saiano F, Patti B, Sprovieri M, Bonanno A, Spoto S. Trace element distributions in the Strait of Sicily (central Mediterranean sea). I. Evidence of rock-water interactions and pollution. Period Mineral 2002;71(3):255-72.

Chalmers AT, Van Metre PC, Callender E. The chemical response of particle-associated contaminants in aquatic sediments to urbanization in New England, U.S.A.. J Contam Hydrol 2007;91(1-2):4-25.

Chan PK, Cheng SH. Cadmium-induced ectopic apoptosis in zebrafish embryos. Arch Toxicol 2003;77(2):69-79.

Cheng SH, Chan KW, Chan PK, So CH, Lam PK, Wu RS. Whole-mount in situ TUNEL method revealed ectopic pattern of apoptosis in cadmium treated naupliar larvae of barnacle (Balanus amphitrite Darwin). Chemosphere 2004;55(10):1387-94.

Ercal N, Gurer-Orhan H, Aykin-Burns N. Toxic metals and oxidative stress part I: mechanisms involved in metalinduced oxidative damage. Curr Top Med Chem 2001;1 (6):529-39, Review.

Foulkes EC. Transport of toxic heavy metals across cell membranes. Review Article. Proc Soc Exp Biol Med 2000;223:234-40.

Goldstone JV, Hamdoun A, Cole BJ, Howard-Ashby M, Nebert DW, Scally M, Dean M, Epel D, Hahn ME, Stegeman JJ. The chemical defensome: environmental sensing and response genes in the Strongylocentrotus purpuratus genome. Dev Biol 2006;300(1):366-84.

Habeebu SS, Liu J, Klaassen CD. Cadmium-induced apoptosis in mouse liver. Toxicol Appl Pharmacol 1998;149(2):203-9.

Hamada T, Tanimoto A, Sasaguri Y. Apoptosis induced by cadmium. Apoptosis 1997;2(4):359-67.

Hamdoun A, Epel D. Embryo stability and vulnerability in an always changing world. Proc Natl Acad Sci USA 2007;104(6):1745-50, Review.

Haouem S, Hmad N, Najjar MF, El Hani A, Sakly R. Accumulation of cadmium and its effects on liver and kidney functions in rats given diet containing cadmium-polluted radish bulb. Exp Toxicol Pathol 2007;59(Issue 1):77-80.

Hart MW. The functional and evolutionary significance of variation in feeding larval forms of echinoderms. Invertebr Biol 1996;115:30-45.

Hays GC, Richardson AJ, Robinson C. Climate change and marine plankton. Trends Ecol Evol 2005;20(6):337-44.

Ishido M, Tohyama C, Suzuki T. Cadmium-bound metallothionein induces apoptosis in rat kidneys, but not in cultured kidney LLC-PK1 cells. Life Sci 1999;64(9):797804.

Kesseler A, Brand MD. Localisation of the sites of action of cadmium on oxidative phosphorylation in potato tuber mitochondria using top-down elasticity analysis. Eur J Biochem 1994;225(3):897-906.

Kim BJ, Kim MS, Kim KB, Kim KW, Hong YM, Kim IK, Lee HW, Jung YK. Sensitizing effects of cadmium on TNF- 
alpha- and TRAIL-mediated apoptosis of NIH3T3 cells with distinct expression patterns of p53. Carcinogenesis 2002;23(9):1411-7.

Kobayashi N, Okamura H. Effects of heavy metals on sea urchin embryo development. 1. Tracing the cause by the effects. Chemosphere 2004;55(10):1403-12.

Kobayashi N, Okamura H. Effects of heavy metals on sea urchin embryo development. Part 2. Interactive toxic effects of heavy metals in synthetic mine effluents. Chemosphere 2005;61:1198-203.

Kremling K, Streu P. Behaviour of dissolved Cd, Co, Zn, and $\mathrm{Pb}$ in North Atlantic near-surface waters $\left(30^{\circ} \mathrm{N} / 60^{\circ} \mathrm{W}\right.$ to $\left.60^{\circ} \mathrm{N} / 2^{\circ} \mathrm{W}\right)$. Deep Sea Res I 2001;48/12:2541-67.

Lesser MP, Kruse VA, Barry TM. Exposure to ultraviolet radiation causes apoptosis in developing sea urchin embryos. J Exp Biol 2003;206(Pt 22):4097-103.

Lin AJ, Zhang XH, Chen MM, Cao Q. Oxidative stress and DNA damages induced by cadmium accumulation. J Environ Sci (China) 2007;19(5):596-602.

Mouchet F, Baudrimont M, Gonzalez P, Cuenot Y, Bourdineaud JP, Boudou A, Gauthier L. Genotoxic and stress inductive potential of cadmium in Xenopus laevis larvae. Aquat Toxicol 2006;78(2):157-66.

Mouchet F, Gauthier L, Baudrimont M, Gonzalez P, Mailhes C, Ferrier V, Devaux A. Comparative evaluation of the toxicity and genotoxicity of cadmium in amphibian larvae (Xenopus laevis and Pleurodeles waltl) using the comet assay and the micronucleus test. Environ Toxicol 2007;22(4):422-35.

Pellerito C, D'Agati P, Fiore T, Mansueto C, Mansueto V, Stocco G, Nagy L, Pellerito L. Synthesis, structural investigations on organotin(IV) chlorin-e6 complexes, their effect on sea urchin embryonic development and induced apoptosis. J Inorg Biochem 2005;99(6):1294305.

Pohl C, Hennings U. The coupling of long-term trace metal trends to seasonal diffusive trace metal fluxes at the oxicanoxic interface in the Gotland Basin; $\left(57^{\circ} 19.20^{\prime} \mathrm{N} ; 20^{\circ}\right.$ 03.00’ E) Baltic Sea. J Mar Sys 2005;56:207-25.

Radakovitch O, Roussiez V, Ollivier P, Ludwig W, Grenz C, Probst J. Input of particulate heavy metals from rivers and associated sedimentary deposits on the Gulf of Lion continental shelf. Estuarine, Coastal and Shelf Science. 2008; (in press).

Rainbow PS, Black WH. Cadmium, zinc and the uptake of calcium by two crabs, Carcinus maenas and Eriocheir sinensis. Aquat Toxicol 2005;72(1-2):45-65.

Risso-de Faverney C, Devaux A, Lafaurie M, Girard JP, Bailly $\mathrm{B}$, Rahmani R. Cadmium induces apoptosis and genotoxicity in rainbow trout hepatocytes through generation of reactive oxygene species. Aquat Toxicol 2001;53(1):65-76.

Roccheri MC, Tipa C, Bonaventura R, Matranga V. Physiological and induced apoptosis in sea urchin larvae undergoing metamorphosis. Int J Dev Biol 2002;46(6):801-6.

Roccheri MC, Agnello M, Bonaventura R, Matranga V. Cadmium induces the expression of specific stress proteins in sea urchin embryos. Biochem Biophys Res Commun 2004;321:80-7.
Roesijadi G, Hansen KM, Unger ME. Cadmium-induced metallothionein expression during embryonic and early larval development of the mollusc Crassostrea virginica. Toxicol Appl Pharmacol 1996;140(2):356-63.

Rule KL, Comber SD, Ross D, Thornton A, Makropoulos CK, Rautiu R. Diffuse sources of heavy metals entering an urban wastewater catchment. Chemosphere 2006;63 (1):64-72.

Russo R, Bonaventura R, Zito F, Schröder HC, Müller I, Müller WE, Matranga V. Stress to cadmium monitored by metallothionein gene induction in Paracentrotus lividus embryos. Cell Stress Chaperones 2003;8(3):232-41.

Sato Y, Kaneko H, Negishi S, Yazaki I. Larval arm resorption proceeds concomitantly with programmed cell death during metamorphosis of the sea urchin Hemicentrotus pulcherrimus. Cell Tissue Res 2006;326(3):851-60.

Schröder HC, Hassanein HMA, Lauenroth S, Koziol C, Mohamed TAA, Lacorn M, Steinhart H, Batel R, Müller WEG. Induction of DNA strand breaks and expression of HSP70 and GRP78 homolog by cadmium in the marine sponge Suberites domuncula. Arch Environ Contam Toxicol 1999;36:47-55.

Schröder HC, Di Bella G, Janipour N, Bonaventura R, Russo R, Müller WEG, Matranga V. DNA damage and developmental defects after exposure to UV and heavy metals in sea urchin cells and embryos compared to other invertebrates. Prog Mol Subcell Biol 2005;39:111-37.

Shimizu M, Hochadel JF, Waalkes MP. Effects of glutathione depletion on cadmium-induced metallothionein synthesis, cytotoxicity, and proto-oncogene expression in cultured rat myoblasts. J Toxicol Environ Health 1997;51:609-21.

Sunda WG, Huntsman S. Processes regulating cellular metal accumulation and physiological effects: Phytoplankton as model systems. Total Environ 1998;219:165-81.

Tankere SPC, Statham PJ. Distribution of dissolved Cd, Cu, Ni and $\mathrm{Zn}$ in the Adriatic Sea. Mar Pollut Bull 1996;32:62330 .

Tsangaris GT, Tzortzatou-Stathopoulou F. Cadmium induces apoptosis differentially on immune system cell lines. Toxicology 1998;128(2):143-50.

Vega RL, Epel D. Stress-induced apoptosis in sea urchin embryogenesis. Mar Environ Res 2004;58(2-5):799-802.

Vega Thurber R, Epel D. Apoptosis in early development of the sea urchin, Strongylocentrotus purpuratus. Dev Biol 2007;303(1):336-46.

Viarengo A, Nicotera P. Possible role of $\mathrm{Ca}^{2+}$ in heavy metal cytotoxicity. Comp Biochem Physiol 1991;100C:81-4.

Waalkes MP, Rehm S. Lack of cacinogenicity of cadmium chloride in female Syrian hamsters. Toxicology 1998;126 (3):173-8.

Yazaki I. Mechanisms of sea urchin metamorphosis: stimuli and responses. In: Yokota Y, Matranga V, Smolenicka Z, editors. The sea urchin: from basic biology to aquaculture. The Netherlands: Balkema, Lisse; 2002. p. 51-71.

Yokota Y, Matranga V, Smolenicka Z. The sea urchin: from basic biology to aquaculture. The Netherlands: Balkema, Lisse; 2002. p. 1-231. 